\title{
Characterization of fruits from the savanna: Araça (Psidium guinnensis Sw.) and Marolo (Annona crassiflora Mart.)
}

\author{
Caracterização dos frutos do Cerrado: Araçá (Psidium guinnensis Sw.) e Marolo (Annona crassiflora Mart.) \\ Clarissa DAMIANI ${ }^{1 \star}$, Eduardo Valério de Barros VILAS BOAS ${ }^{2}$, Eduardo Ramirez ASQUIERI ${ }^{4}$, \\ Moacir Evandro LAGE 3 , Rodrigo Almeida de OLIVEIRA ${ }^{3}$, Flavio Alves da SILVA ${ }^{1}$, Daniella Moreira PINTO ${ }^{2}$, \\ Luiz José RODRIGUES², Edson Pablo da SILVA², Nélio Ranieli Ferreira de PAULA²
}

\begin{abstract}
The objective of this work was to characterize fruits from the Brazilian savanna by means of physical and chemical analyses. The results obtained

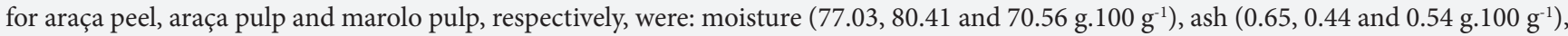
protein $\left(1.39,1.87\right.$ and $\left.1.99 \mathrm{~g} .100 \mathrm{~g} \mathrm{~g}^{-1}\right)$, lipids $\left(0.32,0.33\right.$ and $\left.2.36 \mathrm{~g} .100 \mathrm{~g}^{-1}\right)$, total carbohydrates $\left(90.88,78.25\right.$ and $\left.24.55 \mathrm{~g} .100 \mathrm{~g}^{-1}\right)$, total soluble sugars $\left(8.45,9.99\right.$ and $\left.127.4 \mathrm{~g} .100 \mathrm{~g}^{-1}\right), \mathrm{pH}(3.76,3.99$ and 4.49$)$, soluble solids ( $11^{\circ}$ Brix, $8.8^{\circ} \mathrm{Brix}$ and $21.4^{\circ}$ Brix $)$ and antioxidant potential $\left(16.33,12.75\right.$ and 34.29 discoloration DPPH/100 mL). Calcium was the predominant mineral in araça $\left(490 \mathrm{mg}^{-\mathrm{kg}^{-1}}\right.$ peel and $\left.485 \mathrm{mg} . \mathrm{kg}^{-1} \mathrm{pulp}\right)$ while magnesium was in marolo $\left(350 \mathrm{mg} \cdot \mathrm{kg}^{-1}\right)$. Citric acid was the predominant organic acid in araça $\left(3125 \mu \mathrm{g} \cdot \mathrm{g}^{-1} \mathrm{peel} \mathrm{and} 881.25 \mu \mathrm{g} \cdot \mathrm{g}^{-1} \mathrm{pulp}\right)$ and Malic acid was predominant in marolo $\left(76.68 \mu \mathrm{g} \cdot \mathrm{g}^{-1}\right)$. Therefore, given their nutrient contents, the consumption of these fruits from the savanna should be encouraged.
\end{abstract}

Keywords: Brazilian fruit; physicochemical characterization; nutritional characterization.

\section{Resumo}

O objetivo deste trabalho foi a caracterização dos frutos do cerrado, por meio de análises físicas e químicas. Os resultados obtidos, a partir da casca de araçá, polpa de araçá e polpa do marolo foram: umidade $\left(77,03 ; 80,41\right.$; e 70,56 g. $\left.100 \mathrm{~g}^{-1}\right)$, cinzas $\left(0,65 ; 0,44 ;\right.$ e 0,54 g.100 g g $\left.^{-1}\right)$, proteína $\left(1,39 ; 1,87 ;\right.$ e 1,99 g. $\left.100 \mathrm{~g}^{-1}\right)$, lipídios $\left(0,32 ; 0,33\right.$; e $\left.2,36 \mathrm{~g} .100 \mathrm{~g}^{-1}\right)$, carboidratos totais $\left(90,88 ; 78,25\right.$; e 24,55 g. $\left.100 \mathrm{~g}^{-1}\right)$, açúcares solúveis totais (8,45; 9,99; e 127,4 g. $\left.100 \mathrm{~g}^{-1}\right)$, pH (3,76; 3,99; e 4,49), sólidos solúveis ( $11^{\circ}$ Brix; 8,8 ${ }^{\circ}$ Brix; e $21,4{ }^{\circ}$ Brix) e potencial antioxidante (16,33; 12,75 ; e 34,29 descoloração DPPH/100 mL). O mineral predominante no araçá foi o cálcio (490 mg. $\mathrm{kg}^{-1}$ casca e $485 \mathrm{mg} . \mathrm{kg}^{-1} \mathrm{de}$ polpa) e na polpa de marolo foi o magnésio $\left(350 \mathrm{mg} \cdot \mathrm{kg}^{-1}\right)$. O ácido orgânico predominante no araçá foi o ácido cítrico $\left(3125 \mu \mathrm{g} \cdot \mathrm{g}^{-1} \mathrm{casca}\right.$ e $881,25 \mu \mathrm{g} \cdot \mathrm{g}^{-1}$ de polpa $\mathrm{e}$ no marolo foi o ácido málico $\left(76,68 \mu \mathrm{g} . \mathrm{g}^{-1}\right)$. Portanto, dado o seu teor de nutrientes, o consumo desses frutos do cerrado deve ser incentivado. Palavras-chave: frutas brasileiras; caracterização física e química; caracterização nutricional.

\section{Introduction}

Currently, health concerns have increased consumers' demand for low-calorie, healthful foods which offer flavor, aroma and diversity.

Savanna fruits are an excellent option in this context, since most of them are rich in pigments and have distinctive aromas. The savanna is an important Brazilian eco-system with a large number of fruit species. Many of these fruits are edible and have been consumed by human populations for a long time, as in the case of araça and marolo. However, little is known about their physical, chemical and biochemical characteristics such as their nutritional composition, antioxidant potential and mineral profile.

Thus, the characterization of these savanna fruits is necessary since these species are already consumed and others may start being consumed in the future, if previously analyzed.
Psidium guineensis Sw. is a small bush and its fruit is known by several names, such as araçai, araça-do-campo, araça-mirim, goiaba-da-guiné and araça-azedo. This fruit, which can be eaten raw or in the form of desserts, drinks, ice cream and liqueurs, is a globular berry with whitish yellow, greenish yellow, pale yellow or yellow color when ripe. The pulp is fleshy, white, mucilaginous, sweet, slightly tart and aromatic, and it has numerous small seeds (MANICA, 2000).

The fruit of Psidium guineensis Sw contains $89.91 \%$ water, $0.80 \%$ ash, $1.54 \%$ malic acid, $5.54 \%$ sugars, $2.55 \%$ cellulose and $0.20 \%$ fat (MANICA, 2000). Franco (1999) found $48 \mu \mathrm{g}$ retinol, $60 \mu \mathrm{g}$ thiamin, $40 \mu \mathrm{g}$ riboflavin, $1.3 \mathrm{mg}$ niacin, $326 \mathrm{mg}$ ascorbic acid, $8 \mathrm{~g}$ sugars, $1 \mathrm{~g}$ protein, $0.2 \mathrm{~g}$ lipids, $14 \mathrm{mg}$ calcium, $30 \mathrm{mg}$ phosphorus, $1.05 \mathrm{mg}$ iron and $37.8 \mathrm{kcal}$ in $100 \mathrm{~g}$ of the araça fruit. Andrade, Aragão and Ferreira (1993) found 85 to $86 \%$ moisture

\footnotetext{
Received 1/12/2009

Accepted 17/5/2010 (004531)

Departamento de Engenharia de Alimentos, Escola de Agronomia e Engenharia de Alimentos, Universidade Federal de Goiás - UFG, Campus Samambaia,

Rod. Estrada Goiânia, Km 0, CEP 74001-970, Nova Veneza, Goiânia, GO, Brazil, e-mail: damianiclarissa@hotmail.com

2 Departamento de Ciência e Tecnologia de Alimentos, Universidade Federal de Lavras - UFLA

3 Centro de Pesquisa em Alimentos, Escola de Veterinária, Universidade Federal de Goiás - UFG

${ }^{4}$ Laboratório de Química e Bioquímica de Alimentos, Faculdade de Farmácia, Universidade Federal De Goiás - UFG

${ }^{*}$ Corresponding author
} 
content, pH 3.0, $1.87 \%$ citric acid, $11^{\circ} \mathrm{Brix}, 5.05 \%$ sugars, $0.103 \mathrm{mg}$ carotenoids and $389.34 \mathrm{mg}$ vitamin C in Psidium acutangulum D.C. Nevertheless, its chemical composition can vary according to rainfall, altitude, climate and soil in the regions where it is harvested (CALDEIRA et al., 2004), and also, according to the origin of its genetic material, the period of production and fruit maturation - with all features influencing on its composition and nutritional value (BEZERRA et al., 2006).

The fruit commonly known as marolo, araticum or cabeça-de-negro, is a somewhat globular berry, which is green when in development and brown when ripe (LORENZI, 1998). The pulp is slightly sweet with a pleasant aroma, and the color ranges from white to yellow. The taste and aroma of the yellow-pulped fruit are stronger than the white one, and they are also more appreciated by consumers. The pulp may be consumed raw, but there are numerous recipes for desserts and drinks that feature the strong and fragrant flavor of this fruit (CARVALHO, 2002). According to Franco (1999), $100 \mathrm{~g}$ of marolo contain $453 \mu \mathrm{g}$ thiamin, $100 \mu \mathrm{g}$ riboflavin, $2.675 \mathrm{mg}$ niacin, $10.3 \mathrm{~g}$ sugars, $0.4 \mathrm{~g}$ proteins, $1.6 \mathrm{~g}$ lipids, $52 \mathrm{mg}$ calcium, $24 \mathrm{mg}$ phosphorus, $2.3 \mathrm{mg}$ iron and $52 \mathrm{kcal}$. However, this species (A. crassiflora) is endangered due to deforestation in the Brazilian savanna (MELO, 2006).

Given the importance of fruit in the human diet and the limited number of studies concerning the fruits found in the savanna of the State of Minas Gerais, Brazil, the purpose of the present study was to characterize the fruits of the araça bush (Psidium guineensis Sw.) and marolo bush (Annona crassiflora Mart.), by means of proximate composition and other physicochemical analyses.

\section{Materials and methods}

Fruit from the 2008 harvest was used. The harvesting period was from February to April for araça and from March to April for marolo; the fruit came from the State of Minas Gerais, Brazil. The fruits were selected on the basis of their appearance and the absence of injuries, rot and characteristic rotting odor. All fruits were first washed to remove surface impurities and rinsed under running water, and then submerged for 20 minutes in a sodium hypochlorite solution at $100 \mu \mathrm{l} . \mathrm{L}^{-1}$ for araça and $300 \mu \mathrm{l} . \mathrm{L}^{-1}$ for marolo.

Some of the hygienized fruits were then separated for characterization. The peel and pulp of the araça and the pulp of the marolo were characterized by way of the following analyses: proximate composition, $\mathrm{pH}$, soluble solids, total and reducing sugars, sucrose, dietary fiber, minerals $(\mathrm{Ca}, \mathrm{Mg}, \mathrm{Zn}$, $\mathrm{Fe}, \mathrm{Cu}$ and $\mathrm{P}$ ), titratable acidity, organic acids (citric, malic, acetic, tartaric and ascorbic), antioxidant potential (ethereal, alcoholic and aqueous extract), total and soluble pectins, phenolic compounds (alcoholic and aqueous extract), firmness and color $\left(\mathrm{L}^{*}, \mathrm{a}^{*} \mathrm{e} \mathrm{b}\right)$, with 15 repetitions. The 15 repetitions were organized as follows: the fruits harvested represented a single batch - this was divided into 15 sub-batches and 1 sample was removed from each sub-batch to carry out all the analyses.
The physical and chemical analyses were the following:

- Coloration: determined using a CR-400 Minolta colorimeter in the CIE $\mathrm{L}^{*}, \mathrm{a}^{*}$ and $\mathrm{b}^{\star}$ mode. Readings were taken at three distinct points on each fruit.

- Firmness: Determined using a Stable Micro System Texturometer TAXT2 (Texture Techologies Corp.);

- Total and soluble pectin: method described by Bitter and Muir (1962);

- Moisture, proteins, lipids, fibers, ash, $\mathrm{pH}$, total soluble solids and titratable acidity: AOAC (ASSOCIATION..., 1997);

- Total carbohydrates and caloric value: method described by Dubois et al. (1956) and Wilson, Santos and Vieira (1982);

- Total and reducing sugars and sucrose: method described by Nelson (1944);

- Minerals: determined using a Varian SpectrAA 110 atomic absorption spectrometer, with wavelength, slot and gas mixture calibrated specifically for each element. Ampules of Merck atomic absorption standard, duly diluted with deionized water, were used to construct the calibration curves;

- Organic acids: extraction as described by Bazimarakenga, Simard and Leurox (1995) and modified by Silva et al. (2001), and identification and quantification by HPLC (High Performance Liquid Chromatography) using a Shimadzu CLASS LC 10 chromatograph equipped with a SPD-M10A UV detector, at a wavelength of $230 \mathrm{~nm}$, using a C-18 reverse phase column $(150 \times 4.6 \mathrm{~mm})$. The sample injection volume was approximately $20 \mu \mathrm{L}$, using water containing $0.1 \%$ phosphoric acid as the mobile phase, and a flux of $1 \mathrm{~mL} /$ minute. The peaks corresponding to each acid were identified by their retention times, using standard retention times for comparison;

- Antioxidant potential: determined by the DPPH method as described by Brand-Williams, Cuvelier and Berset (1995) and modified by Borguini (2006). The degree of discoloration of the DPPH radical at $517 \mathrm{~nm}$ by the action of the antioxidants was measured spectrophotometrically (Shimadzu mod. UV-1601 PC) in the ethereal, alcoholic and aqueous extracts with a concentration $0.2 \mathrm{mg} \cdot \mathrm{mL}^{-1}$ and the results expressed as DPPH discoloration. $100 \mathrm{~g}^{-1}$;

- Phenolic compounds: extraction of the alcoholic and aqueous compounds was carried out as described by Genovese et al. (2003) for the determination of total phenols using the Folin-Ciocalteu reagent. The determination of these phenols was described by Zieliski and Kozowaska (2000) and the results were expressed as mg GAE.100 g-1 .

To evaluate the results of the chemical and physical analyses of the araça and marolo pulps and the araça peel, the means, standard deviations and coefficients of variation were calculated.

\section{Results and discussion}

Table 1 shows the results obtained in the characterization of the araça fruit (Psidium guineensis Sw.). 
The results show that the average mass of the araça fruit was $10.7 \mathrm{~g}$, a value comparable to that found by Caldeira et al. (2004) when analyzing araça fruits from the State of Mato Grosso do Sul, Brazil (9.28 g).

The araça species studied here conforms to the average characteristics evaluated for 40 different araça fruits identified in 35 Brazilian eco-regions (SANTOS et al., 2008), namely small fruits with dark green skin and cream-colored pulp. This can be confirmed from the $L^{*}$ value $(52.58 \pm 1.54), \mathrm{a}^{*}$ value $(10.70 \pm 0.99)$ and $b^{*}$ value $(28.64 \pm 1.22)$ - the color parameters found for the peel of the fruit from southern Minas Gerais studied in this paper.

The firmness of the ripe fruit was $0.43 \mathrm{~N}$ (Newton), in line with the high soluble pectin level in both the pulp $\left(0.50 \mathrm{~g} .100 \mathrm{~g}^{-1}\right)$ and the peel $\left(0.44 \mathrm{~g} .100 \mathrm{~g}^{-1}\right)$. In the ripening process, enzymes such as PG (polygalacturonase) and PME (pectinmethylesterase) act to degrade the total pectin amount, making it soluble and, consequently, softening the fruit. The total amount of pectin found was $0.72 \mathrm{~g} .100 \mathrm{~g}^{-1}$ for the araça pulp and $0.82 \mathrm{~g} .100 \mathrm{~g}^{-1}$ for the araça peel, with solubility of $69.4 \mathrm{~g} .100 \mathrm{~g} \mathrm{~g}^{-1}$ and $53.65 \mathrm{~g} .100 \mathrm{~g}^{-1}$, respectively, resulting in low firmness.

As far as the proximate composition was concerned, the moisture content was $80.41 \mathrm{~g} .100 \mathrm{~g} \mathrm{~g}^{-1}$ for the pulp and $77.03 \mathrm{~g} .100 \mathrm{~g} \mathrm{~g}^{-1}$ for the skin, values similar to those found by Caldeira et al. (2004) for the whole fruit $\left(85 \mathrm{~g} .100 \mathrm{~g}^{-1}\right)$. The high moisture content made the fruit more susceptible to deterioration, making rapid consumption after ripening or rapid technological processing into desserts, jams, juices, nectars, etc., necessary.
The protein and lipid levels encountered were $1.87 \mathrm{~g} .100 \mathrm{~g}^{-1}$ (pulp) and 1.39 g. $100 \mathrm{~g}^{-1}$ (skin) and $0.33 \mathrm{~g} .100 \mathrm{~g}^{-1}$ (pulp) and 0.32 g. $100 \mathrm{~g}^{-1}$ (skin), respectively. These values differed from those found by Caldeira et al. (2004) - 10\% proteins and 1.02\% lipids, but they were similar to those observed by Franco (1999) when analyzing white guava protein contents $\left(1.09 \mathrm{~g} .100 \mathrm{~g}^{-1}\right)$ and araça lipid contents $\left(0.2 \mathrm{~g} .100 \mathrm{~g}^{-1}\right)$. This difference may arise from differences in the growing conditions (soil, climate, precipitation) and maturation stage (SANTOS, 2003).

The total carbohydrate content was $16.95 \mathrm{~g} .100 \mathrm{~g}^{-1}$ for the pulp and $20.61 \mathrm{~g} .100 \mathrm{~g}^{-1}$ for the peel, thus determining the caloric value of $78.25 \mathrm{kcal}$ for the araça pulp and $90.88 \mathrm{kcal}$ for the peel. The total soluble sugars and fibers are included in the class of carbohydrates. The total soluble sugar levels were $9.99 \mathrm{~g} .100 \mathrm{~g}^{-1}$ for the pulp and $8.45 \%$ for the peel. Out of all these sugars, $5.91 \mathrm{~g} .100 \mathrm{~g} \mathrm{~g}^{-1}$ were reducing sugars (glucose and fructose)

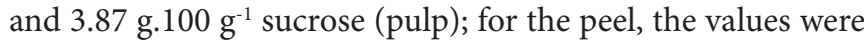
$5.07 \mathrm{~g} .100 \mathrm{~g}^{-1}$ reducing sugars and $3.2 \%$ sucrose. The soluble solid contents were $10.7^{\circ} \mathrm{Brix}$ for the pulp and $11^{\circ} \mathrm{Brix}$ for the skin.

The levels of crude total fiber were $4.82 \mathrm{~g} .100 \mathrm{~g}^{-1}$ for the pulp and $6.13 \mathrm{~g} .100 \mathrm{~g}^{-1}$ for the skin. According to Directive no. 27 (BRASIL, 1998) a product must contain a minimum of $3 \mathrm{~g} .100 \mathrm{~g}^{-1}$ food solids to be considered a source of dietary fiber. Thus, araça is an excellent source of dietary fiber.

Table 2 shows the results obtained in the analyses of ash, minerals, acidity and organic acid.

The level of ash was $0.44 \%$ for the pulp and $0.65 \%$ for the skin, similar to the levels found for the whole araça

Table 1. Physical and chemical characterization of the araça fruit (Psidium guineensis Sw.), native to the southern region of the State of Minas Gerais, Brazil, with the respective standard deviations (coefficient of variation) on wet weight basis.

\begin{tabular}{|c|c|c|c|c|c|}
\hline \multirow[t]{2}{*}{ Analyses } & \multicolumn{2}{|c|}{ Mean } & \multirow[t]{2}{*}{ Analyses } & \multicolumn{2}{|c|}{ Mean } \\
\hline & Pulp & Peel & & Pulp & Peel \\
\hline Mean mass per fruit (g) & \multicolumn{2}{|c|}{$10.7 \pm 0.89(1.78)$} & Lipids (g.100 g $\left.{ }^{-1}\right)$ & $0.33 \pm 0.11(1.35)$ & $0.32 \pm 0.17(1.45)$ \\
\hline$L^{\star}$ value & \multicolumn{2}{|c|}{$52.58 \pm 1.54(1.88)$} & Total carbohydrate (g.100 g $\left.\mathrm{g}^{-1}\right)$ & $16.95 \pm 0.15(0.67)$ & $20.61 \pm 0.25(1.02)$ \\
\hline $\mathrm{a}^{*}$ value & \multicolumn{2}{|c|}{$10.7 \pm 0.99(1.35)$} & Calories (kcal) & $78.25 \pm 0.08(0.78)$ & $90.88 \pm 0.1(0.890$ \\
\hline $\mathrm{b}^{*}$ value & \multicolumn{2}{|c|}{$28.64 \pm 1.22(1.64)$} & Soluble sugar $\left(\mathrm{g} .100 \mathrm{~g}^{-1}\right)$ & $9.99 \pm 0.08(0,48$ & $8.45 \pm 0.05(0,56)$ \\
\hline Firmness $\left(\mathrm{N}^{\star}\right)$ & \multicolumn{2}{|c|}{$0.43 \pm 0.57(1.45)$} & Reducing sugar (g.100 g-1) & $5.91 \pm 0.26(1.14)$ & $5.07 \pm 0.17(1.23)$ \\
\hline Soluble pectin $\left(\mathrm{g} .100 \mathrm{~g}^{-1}\right)$ & $0.5 \pm 0.06(1.45)$ & $0.44 \pm 0.07(1.76)$ & Sucrose $\left(\mathrm{g} .100 \mathrm{~g}^{-1}\right)$ & $3.87 \pm 0.07(0.58)$ & $3.20 \pm 0.03(0.44)$ \\
\hline Total pectin (g.100 g-1) & $0.72 \pm 0.03(1.1)$ & $0.82 \pm 0.08$ & Soluble solids $\left({ }^{\circ} \mathrm{Brix}\right)$ & $10.7 \pm 0.12(0.85)$ & $11 \pm 0.09(0.88)$ \\
\hline Moisture (g.100 g $\mathrm{g}^{-1}$ ) & $80.41 \pm 0.35(0.43)$ & $77.03 \pm 0.25(0.56)$ & Fiber $\left(\mathrm{g} .100 \mathrm{~g}^{-1}\right)$ & $4.82 \pm 0.04(0.23)$ & $6.13 \pm 0.89(0.31)$ \\
\hline Protein $\left(\mathrm{g} .100 \mathrm{~g}^{-1}\right)$ & $1.87 \pm 0.65(1.02)$ & $1.39 \pm 0.76(1.11)$ & & & \\
\hline
\end{tabular}

Table 2. Ash, mineral, acidity and organic acid contents of the araça fruit (Psidium guineensis Sw.), native to the southern region of the State of Minas Gerais, Brazil, with the respective standard deviations (coefficient of variation) (wet weight basis).

\begin{tabular}{|c|c|c|c|c|c|}
\hline \multirow[t]{2}{*}{ Analyses } & \multicolumn{2}{|c|}{ Mean } & \multirow[t]{2}{*}{ Analyses } & \multicolumn{2}{|c|}{ Mean } \\
\hline & Pulp & Peel & & Pulp & Peel \\
\hline Ash (g.100 g $\left.\mathrm{g}^{-1}\right)$ & $0.44 \pm 0.02(0.98)$ & $0.65 \pm 0.04(0.78)$ & Titratable acid $\left(\mathrm{g} .100 \mathrm{~g}^{-1}\right)$ & $0.52 \pm 0.01(0.11)$ & $0.74 \pm 0.03(0.2)$ \\
\hline Calcium (mg.kg-1) & $485.0 \pm 0.01(0.89)$ & $490.0 \pm 0.02(0.77)$ & $\mathrm{pH}$ & $3.99 \pm 0.01(0.17)$ & $3.76 \pm 0.02(0.23)$ \\
\hline Magnesium (mg.kg-1) & $292 \pm 0.02(0.78)$ & $282 \pm 0.01(0.99)$ & Ascorbic acid $\left(\mu \mathrm{g} . \mathrm{g}^{-1}\right)$ & $142.5 \pm 0.0(0.0)$ & $377.5 \pm 0.0(0.0)$ \\
\hline Zinc $\left(\mathrm{mg} \cdot \mathrm{kg}^{-1}\right)$ & $2.72 \pm 002(0.88)$ & $11.2 \pm 0,01(0.69)$ & Citric acid $\left(\mu \mathrm{g} \cdot \mathrm{g}^{-1}\right)$ & $881.25 \pm 0.0(0.0)$ & $3125 \pm 0.0(0.0)$ \\
\hline Iron $\left(\mathrm{mg} \cdot \mathrm{kg}^{-1}\right)$ & $5.48 \pm 0.01(0.71)$ & $4.95 \pm 0.03(0.56)$ & Malic acid ( $\left.\mu g \cdot g^{-1}\right)$ & $761.3 \pm 0.0(0.0)$ & $1265 \pm 0.0(0.0)$ \\
\hline Copper (mg.kg $\left.{ }^{-1}\right)$ & $3.2 \pm 0.03(0.69)$ & $3.4 \pm 0.01(0.99)$ & Tartaric acid ( $\mu$ g.g $\left.\mathrm{g}^{-1}\right)$ & $296.3 \pm 0.0(0.0)$ & $156.4 \pm 0.0(0.0)$ \\
\hline Phosphorus (mg.kg ${ }^{-1}$ ) & $97.5 \pm 0.02(0.69)$ & $66.0 \pm 0.01(0.72)$ & Acetic acid $\left(\mu \mathrm{g} \cdot \mathrm{g}^{-1}\right)$ & 0.0 & 0.0 \\
\hline
\end{tabular}


fruit by Bezerra et al. (2006) and for Paluma variety guavas (0.54 g. $\left.100 \mathrm{~g} \mathrm{~g}^{-1}\right)$ by Pereira et al. (2003). Ash represents the levels of minerals incorporated in the sample. The quantity of minerals found in the pulp and skin, respectively, were the following: calcium $485 \mathrm{mg} . \mathrm{kg}^{-1}$ and $490 \mathrm{mg} \cdot \mathrm{kg}^{-1}$; magnesium $292 \mathrm{mg} \cdot \mathrm{kg}^{-1}$ and $282 \mathrm{mg} \cdot \mathrm{kg}^{-1}$; zinc $2.72 \mathrm{mg} \cdot \mathrm{kg}^{-1}$ and $11.2 \mathrm{mg} \cdot \mathrm{kg}^{-1}$; iron $5.48 \mathrm{mg} . \mathrm{kg}^{-1}$ and $4.85 \mathrm{mg} \cdot \mathrm{kg}^{-1}$; copper $3.2 \mathrm{mg} \cdot \mathrm{kg}^{-1}$ and $3.4 \mathrm{mg} \cdot \mathrm{kg}^{-1}$; and phosphorus $97.5 \mathrm{mg} \cdot \mathrm{kg}^{-1}$ and $66 \mathrm{mg} \cdot \mathrm{kg}^{-1}$. The araça from the south of the State of Minas Gerais is a fruit rich in calcium, magnesium and phosphorus, with low levels of zinc, iron and copper. The recommended daily allowance (RDA) according to the IOM (INSTITUTE..., 1997, 2001) is 1,000 mg.day ${ }^{-1}$ of calcium; 350 mg.day ${ }^{-1}$ of magnesium, 10 mg.day $^{-1}$ of zinc, $8 \mathrm{mg}$.day ${ }^{-1}$ of iron, $800 \mathrm{mg} \cdot$ day $^{-1}$ of copper, and $700 \mathrm{mg} \cdot$ day $^{-1}$ of phosphorus. Hence, the araça can contribute effectively to satisfying the need for these minerals. In comparison, the orange contains $380 \mathrm{mg} \cdot \mathrm{kg}^{-1}$ of Ca; the banana contains $288 \mathrm{mg} \cdot \mathrm{kg}^{-1}$ of $\mathrm{Mg}$, the strawberry contains $3.94 \mathrm{mg} \cdot \mathrm{kg}^{-1}$ of $\mathrm{Fe}$, the avocado contains $2.7 \mathrm{mg} \cdot \mathrm{kg}^{-1}$ of $\mathrm{Cu}$, and the pear contains $0.3 \mathrm{mg} \cdot \mathrm{kg}^{-1}$ of $\mathrm{Zn}$, as reported by Cozzolino (2007).

The titratable acidity was 0.52 g. $100 \mathrm{~g} \mathrm{~g}^{-1}$ for the pulp and $0.74 \mathrm{~g} .100 \mathrm{~g}^{-1}$ for the peel, with a pH of 3.99 for the pulp and 3.76 for the peel. In fact, as far as the concentrations of organic acids were concerned, the values obtained for ascorbic acid (Vitamin C), citric acid and malic acid were considerably higher in the peel than in the pulp, as follows: $377.5 \mu \mathrm{g} \cdot \mathrm{g}^{-1}, 142.5 \mu \mathrm{g} \cdot \mathrm{g}^{-1}$ and $3125 \mu \mathrm{g} \cdot \mathrm{g}^{-1}$ in the peel; and $881.25 \mu \mathrm{g} \cdot \mathrm{g}^{-1}, 1265 \mu \mathrm{g} . \mathrm{g}^{-1}$ and $761.3 \mu \mathrm{g} . \mathrm{g}^{-1}$ in the pulp. The exception was tartaric acid, where the concentration was $156.4 \mu \mathrm{g} \cdot \mathrm{g}^{-1}$ in the peel and $296.3 \mu \mathrm{g} . \mathrm{g}^{-1}$ in the pulp. No acetic acid was found in the araça pulp or peel.

Table 3 shows the results obtained in the analysis of the antioxidant potential.

Substances with antioxidant potential showed a total concentration of 12.76 discoloration units. $100 \mathrm{~mL}^{-1}$ for the pulp and 16.33 discoloration units. $100 \mathrm{~mL}^{-1}$ for the peel. Of these substances, 6.52 discoloration units. $100 \mathrm{~g}^{-1}$ and 7.45 discoloration units. $100 \mathrm{~mL}^{-1}$ were present in the ethereal extract; 0.30 discoloration units. $100 \mathrm{~mL}^{-1}$ and 2.95 discoloration units. $100 \mathrm{~mL}^{-1}$ were present in the ethanolic extract; and
5.93 discoloration units. $100 \mathrm{~mL}^{-1}$ were in the aqueous extract of the pulp and peel, respectively. The ethanolic extract had the lowest concentrations of antioxidant substances and the aqueous extract had the same average values for the pulp and peel.

These data can be confirmed by the levels of phenolic compounds found in the fruit in both the ethanolic extract (lower values) and the aqueous extract, since, according to Mahatanatawee et al. (2005), the correlation coefficient between DPPH (the method used in analyzing the antioxidants) and total phenols is 0.96 . In the first (ethanolic) extract, no phenolic compounds were identified in the pulp, but $14.14 \mathrm{mg}$ GAE. $100 \mathrm{~g} \mathrm{~g}^{-1}$ phenolic compounds were found in the peel. In the aqueous extract, the pulp had $113 \mathrm{mg}$ GAE. $100 \mathrm{~g}^{-1}$ and the peel $150 \mathrm{mg}$ GAE. $100 \mathrm{~g}^{-1}$ of phenolic compounds.

Table 4 shows the results obtained in the characterization of the marolo fruit.

The marolo fruit analyzed in this paper presented average yields of 40 g. $100 \mathrm{~g} \mathrm{~g}^{-1}$ peel, $51 \mathrm{~g} .100 \mathrm{~g}^{-1}$ pulp and $9 \mathrm{~g} .100 \mathrm{~g}^{-1}$ seeds. In an investigation of the antioxidant potential of savanna fruits, Roesler et al. (2007) found mean yields of $31.8 \mathrm{~g} .100 \mathrm{~g}^{-1} \mathrm{skin}$, 55.7 g. $100 \mathrm{~g}^{-1}$ pulp and $12.5 \mathrm{~g} .100 \mathrm{~g}^{-1}$ seeds for marolo.

Table 3. Antioxidant potential of the araça fruit (Psidium guineensis Sw.) native to the southern region of the State of Minas Gerais, Brazil, with the respective standard deviations (coefficient of variation) (wet weight basis).

\begin{tabular}{lrr}
\hline \multirow{2}{*}{ Analyses } & \multicolumn{2}{c}{ Mean } \\
\cline { 2 - 3 } & \multicolumn{1}{c}{ Pulp } & \multicolumn{1}{c}{ Peel } \\
\hline $\mathrm{AP}^{*}$ Total & $12.75 \pm 0.54(1.77)$ & $16.33 \pm 0.45(1.75)$ \\
$\mathrm{AP}^{*}(\mathrm{EE})$ & $6.52 \pm 0.66(1.21)$ & $7.45 \pm 0.78(1.98)$ \\
$\mathrm{AP}^{*}(\mathrm{OHE})$ & $0.30 \pm 0.76(1.56)$ & $2.95 \pm 0.69(1.45)$ \\
$\mathrm{AP}^{*}(\mathrm{AE})$ & $5.93 \pm 0.88(1.87)$ & $5.93 \pm 0.67(1.88)$ \\
$\mathrm{TP}^{* *}(\mathrm{OHE})$ & 0.0 & $14.14 \pm 0.23(1.44)$ \\
$\mathrm{TP}^{* *}(\mathrm{AE})$ & $113 \pm 0.77(1.65)$ & $150 \pm 0.54(1.33)$ \\
\hline
\end{tabular}

${ }^{*}$ AP: antioxidant potential expressed as the discoloration of the DPPH radical $/ 100 \mathrm{~mL}$ (EE- ethereal extract, OHE- ethanolic extract, AE- aqueous extract); ${ }^{*} \mathrm{TP}$ : total phenolics expressed in mg GAE (gallic acid equivalent). $100 \mathrm{~g}^{-1}$ (OHE- ethanolic extract, AE- aqueous extract). Standard BHT $0.05 \mathrm{mg} \cdot \mathrm{mL}^{-1}=96.27 \%$ and $0.1 \mathrm{mg} \cdot \mathrm{mL}^{-1}=100 \%$.

Table 4. Physical and chemical characterization of the pulp of the Marolo fruit (Annona crassiflora Mart.) from the state of Minas Gerais, Brazil, with the respective standard deviations (coefficient of variation), (wet weight basis).

\begin{tabular}{|c|c|c|c|}
\hline Analyses & Means $(\mathrm{CV})$ & Analyses & Means $(\mathrm{CV})$ \\
\hline Firmness $\left(\mathrm{N}^{*}\right)$ & $0.29 \pm 0.9(1.67)$ & Soluble solid ( ${ }^{\circ}$ Brix) & $21.4 \pm 0.7(1.37)$ \\
\hline $\mathrm{L}^{\star}$ value & $70.92 \pm 0.7(1.65)$ & $\mathrm{pH}$ & $4.49 \pm 0.4(0.78)$ \\
\hline $\mathrm{a}^{*}$ value & $2.17 \pm 0.69(1.54)$ & Titratable acid (\%) & $0.5 \pm 0.1(0.88)$ \\
\hline $\mathrm{b}^{\star}$ value & $33.90 \pm 0.71(1.87)$ & Vitamin $C\left(\mu g \cdot g^{-1}\right)$ & $9.5 \pm 0.0(0.0)$ \\
\hline Moisture (\%) & $70.56 \pm 0.33(0.77)$ & Citric acid $\left(\mu \mathrm{g} \cdot \mathrm{g}^{-1}\right)$ & $294 \pm 0.0(0.0)$ \\
\hline Proteins (\%) & $1.99 \pm 0.78(1.65)$ & Malic acid $\left(\mu \mathrm{g} \cdot \mathrm{g}^{-1}\right)$ & $958.5 \pm 0,0(0,0)$ \\
\hline Lipids (\%) & $2.36 \pm 0.2(1.48)$ & Tartaric acid ( $\mu$ g. $\left.g^{-1}\right)$ & $0.0 \pm 0.0(0.0)$ \\
\hline Total carbohydrate (\%) & $24.55 \pm 0.11(0.88)$ & Acetic acid ( $\mu g . g-1)$ & $0.0 \pm 0.0(0.0)$ \\
\hline Calories (kcal) & $127.40 \pm 0.56(0.96)$ & Fibers (\%) & $4.46 \pm 0.8(1.67)$ \\
\hline Total sugars $(\%)$ & $16.68 \pm 0.1(0.79)$ & Total pectin $(\%)$ & $1.30 \pm 0.2(1.23)$ \\
\hline Reducing sugars (\%) & $12.38 \pm 0.66(1.2)$ & Soluble pectin (\%) & $0.30 \pm 0.31(1.43)$ \\
\hline Sucrose $(\%)$ & $4.11 \pm 0.34(1.2)$ & & \\
\hline
\end{tabular}

${ }^{\star} \mathrm{N}$ : Newton. 
The firmness of the ripe fruit was $0.29 \mathrm{~N}$ and the results for color were: $\mathrm{L}^{*}$ value 70.92 and $37.10, \mathrm{a}^{*}$ value 2.17 and 7.87 , and $b^{\star}$ value 33.90 and 7.17 for the pulp and peel, respectively. In fact, the pulp has a yellowish cream coloration and, hence, a higher $b^{*}$ value than the skin, as well as a lower $\mathrm{L}^{\star}$ value, since the peel has a dark brownish color.

The moisture, protein and lipid levels observed for the pulp were 70.56 g. $100 \mathrm{~g} \mathrm{~g}^{-1}, 1.99 \mathrm{~g} .100 \mathrm{~g} \mathrm{~g}^{-1}$ and $2.36 \mathrm{~g} .100 \mathrm{~g}^{-1}$, respectively. These values are similar to those found by Roesler et al. (2007):

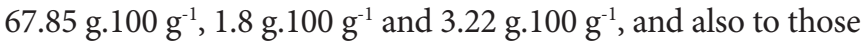
observed by Silva et al. (2008) when evaluating the chemical characteristics of certain savanna fruits: 76.05 g. $100 \mathrm{~g}^{-1}$, $1.22 \mathrm{~g} .100 \mathrm{~g}^{-1}$ and $3.83 \mathrm{~g} .100 \mathrm{~g}^{-1}$. The pulp of the marolo, like that of the araça, has a high moisture content, which makes it rapid deterioration, and also a high lipid content when compared to other traditional edible fruits, and may, thus, undergo rancidity. According to Franco (1999), the sugar-apple (Annona squamosa L.), for example, contains no lipids, while according to TACO (UNIVERSIDADE..., 2006), the atemoya, a cross breed of the sweet-apple and the cherimoya (Annona cherimola, Mill - from the soursop family), contains about $0.3 \mathrm{~g} .100 \mathrm{~g}^{-1}$.

The total carbohydrate and calorie contents for the marolo were $24.55 \mathrm{~g} .100 \mathrm{~g} \mathrm{~g}^{-1}$ and $127.40 \mathrm{kcal}$, values higher than those found by Silva et al. (2008), which were $12.7 \mathrm{~g} .100 \mathrm{~g}^{-1}$ and $90.47 \mathrm{kcal}$, respectively. This difference may be explained by the geographical location of the fruits investigated by these authors, which were obtained in the State of Goias, Brazil. Differences in geographical location imply in heterogeneity in the chemical characteristics of the plant as a whole, but mainly of the fruits.

The total and reducing sugar contents and sucrose

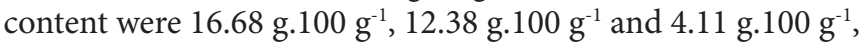
respectively. The total sugar contents were lower than those found by Roesler et al. (2007) and higher than those reported by Agostini, Cecchi and Barrera-Arellano (1995), which were 19.05 g. $100 \mathrm{~g} \mathrm{~g}^{-1}$ and $13 \mathrm{~g} .100 \mathrm{~g}^{-1}$, respectively. However, the reducing sugar levels were similar to those observed by these authors in fruits of the Annona coreaceae species (11.3 g.100 g $\mathrm{g}^{-1}$ ).

The value for soluble solids was $21.4^{\circ} \mathrm{Brix}$, showing that the fruit had a good concentration of soluble sugars and organic acids.

The $\mathrm{pH}$ of the marolo pulp was 4.49 , similar to that found by Roesler et al. (2007), who reported a value of 4.8, and by Agostini, Cecchi and Barrera-Arellano (1995), who observed a pH of 4.7. The titratable acidity was $0.5 \%$, with ascorbic acid, citric acid and malic acid levels of $9.5 \mu \mathrm{g} . \mathrm{g}^{-1}, 294 \mu \mathrm{g} \cdot \mathrm{g}^{-1}$ and $958.5 \mu \mathrm{g} . \mathrm{g}^{-1}$, respectively. No tartaric acid or acetic acid was found in the raw pulp.

The fiber content was $4.46 \%$, similar to that found by Agostini, Cecchi and Barrera-Arellano (1995) with 5.2 g. $100 \mathrm{~g}^{-1}$, and by Silva et al. (2008) with $4.72 \mathrm{~g} .100 \mathrm{~g}^{-1}$. Soluble fiber, represented by the total pectin, was $1.3 \mathrm{~g} .100 \mathrm{gg}^{-1}$, with $0.3 \mathrm{~g} .100 \mathrm{~g} \mathrm{~g}^{-1}$ of soluble pectin. Thus, in accordance with Directive no. 27 (BRASIL, 1998), marolo may also be considered as a rich source of fibers, aiding gastrointestinal function. In general, the water-soluble fibers (pectins, gums, mucilages and certain hemicelluloses) retard the passage through the intestine, the gastric emptying, and the absorption of glucose, helping to reduce cholesterol in the blood serum. Water-insoluble fibers (lignin, cellulose and certain hemicelluloses) accelerate the passage through the intestine, increase the weight of the feces, slow down starch hydrolysis, and retard the absorption of glucose, contributing to a reduction in the risk of certain colon diseases (LEONEL; CEREDA; ROAU, 1999).

Table 5 shows the results for the analyses of ash, minerals and antioxidant potential.

The ash level was $0.54 \%$, similar to the $0.77 \mathrm{~g} .100 \mathrm{~g}^{-1}$ found by Roesler et al (2007). The mineral concentrations were the following: $192 \mathrm{mg} \cdot \mathrm{kg}^{-1}$ of calcium, $350 \mathrm{mg} \cdot \mathrm{kg}^{-1}$ of magnesium, $3.45 \mathrm{mg} . \mathrm{kg}^{-1}$ of zinc, $3.82 \mathrm{mg} \cdot \mathrm{kg}^{-1}$ of iron, $2.2 \mathrm{mg} \cdot \mathrm{kg}^{-1}$ of copper and $220 \mathrm{mg} . \mathrm{kg}^{-1}$ of phosphorus. In studies carried out by Silva et al. (2008), the values were $290 \mathrm{mg} \cdot \mathrm{kg}^{-1}$ for calcium, 7.9 mg. $\mathrm{kg}^{-1}$ for zinc and $4.3 \mathrm{mg} . \mathrm{kg}^{-1}$ for iron; however, for Franco (1999), the values were $520 \mathrm{mg} . \mathrm{kg}^{-1}$ for calcium, $240 \mathrm{mg} \cdot \mathrm{kg}^{-1}$ for phosphorus, and $23 \mathrm{mg} . \mathrm{kg}^{-1}$ for iron. The soil and its nutrients may be the main cause of this difference in the mineral profile.

The marolo pulp from Minas Gerais presented 34.29 discoloration units. $100 \mathrm{~mL}^{-1}$ of total antioxidant potential, where 11.18 discoloration units. $100 \mathrm{~mL}^{-1}$ were found in the ethereal extract, 5.01 discoloration units. $100 \mathrm{~mL}^{-1}$ in the ethanolic extract, and 18.1 discoloration units. $100 \mathrm{~mL}^{-1}$ in the aqueous extract. The degree of discoloration indicates the antioxidant potential of the extract. An extract that presents a high capacity for sequestering free radicals has a low CI (concentration index) value, which is the amount of extract capable of decreasing the initial concentration of the DPPH radical by 50 discoloration units $/ 100 \mathrm{~mL}$ or of inhibiting the oxidation of the radical by 50 discoloration units. $100 \mathrm{~mL}^{-1}$. The $\mathrm{CI}$ values for the ethereal,

Table 5. Ash and mineral contents and the antioxidant potential of the pulp of the Marolo fruit (Annona crassiflora Mart.) from the State of Minas Gerais, Brazil, with the respective standard deviations (coefficient of variation) (wet weight basis).

\begin{tabular}{|c|c|c|c|}
\hline Analyses & Means (CV) & Analyses & Means (CV) \\
\hline Ash (\%) & $0.54 \pm 0.65$ & Total AP* & $34.29 \pm 0.09(0.66)$ \\
\hline Calcium (mg.kg $\left.{ }^{-1}\right)$ & $192.0 \pm 0.1(0.23)$ & $\mathrm{AP}^{\star}(\mathrm{EE})$ & $11.18 \pm 0.12(0.44)$ \\
\hline Magnesium (mg.kg-1 $)$ & $350.0 \pm 0.08(0.32)$ & $\mathrm{AP}^{*}(\mathrm{OHE})$ & $5.01 \pm 0.11(0.32)$ \\
\hline Zinc (mg.kg-1) & $3.45 \pm 0.1(0.54)$ & $\mathrm{AP}^{\star}(\mathrm{AE})$ & $18.10 \pm 0.1(0.57)$ \\
\hline Iron (mg.kg-1) & $3.82 \pm 0.2(0.33)$ & $\mathrm{TP}^{\star \star}(\mathrm{OHE})$ & $211.11 \pm 0.6(1.78)$ \\
\hline Copper (mg.kg-1) & $2.2 \pm 0.1(0.28)$ & $\mathrm{TP}^{\star \star}(\mathrm{AE})$ & $260.50 \pm 0.58(1.87)$ \\
\hline Phosphorus (mg.kg-1) & $220.0 \pm 0.16(0.43)$ & & \\
\hline
\end{tabular}

*AP: antioxidant potential expressed as the discoloration of the DPPH radical/100 $\mathrm{mL}$ (EE- ethereal extract, OHE- ethanolic extract, AE- aqueous extract); ${ }^{* \star} \mathrm{TP}$ : total phenolics expressed in mg GAE (gallic acid equivalent). $100 \mathrm{~g}^{-1}$ (OHE- ethanolic extract, AE- aqueous extract). Standard BHT $0.05 \mathrm{mg} \cdot \mathrm{mL}^{-1}=96.27 \%$ and $0.1 \mathrm{mg} \cdot \mathrm{mL}^{-1}=100 \%$. 
ethanolic and aqueous extracts were $894 \mu \mathrm{g} \cdot \mathrm{mL}^{-1}, 1996 \mu \mathrm{g} \cdot \mathrm{mL}^{-1}$ and $552 \mu \mathrm{g} \cdot \mathrm{mL}^{-1}$, generating a total of $291 \mu \mathrm{g} \cdot \mathrm{mL}^{-1}$. These values are quite different from those reported by Roesler et al. (2007), who obtained CI values of $148 \mu \mathrm{g} \cdot \mathrm{mL}^{-1}$ for the ethanolic extract and $1391 \mu \mathrm{g} \cdot \mathrm{mL}^{-1}$ for the aqueous extract. No data were found concerning the ethereal extract or the total value. This difference may have arisen from the extraction process used, such as the solvent ratio, mass, extraction time and number of re-extractions.

The phenolic compounds were present in both the ethanolic and aqueous extracts, with values of $211.11 \mathrm{mg}$ GAE. $100 \mathrm{~g}^{-1}$ and $260.5 \mathrm{mg}$ GAE. $100 \mathrm{~g}^{-1}$, respectively. The method used to determine the total phenolic compounds in this study allowed for quantification of the flavonoids, anthocyanins and phenolic compounds in the sample - compounds with recognized anti-oxidant capacities.

\section{Conclusions}

As shown in the analyses, araça is a nutritionally rich fruit, presenting fibers and minerals such as calcium, magnesium and phosphorus, as well as some antioxidant potential. The peel, often consumed together with the pulp by the local population, raises the nutritional value of the fruit, since it is rich in organic acids, predominantly citric acid, followed by malic acid.

Marolo is also a nutritionally high-value fruit, since it contains significant levels of lipids, calories and fibers; it is rich in magnesium and phosphorus; it contains malic acid as its predominant acid, and has a good percentage of antioxidant substances. It is also a fruit with great processing potential.

Therefore, the consumption of these two fruits from the savanna of the State of Minas Gerais should be encouraged, because they provide an appreciable amount of nutritious substances and meet the modern consumers' needs for healthier fruits with low calorie contents, but with attractive characteristics such as flavor, aroma and diversity.

\section{Acknowledgements}

The authors are grateful to 'CNPq,' 'CAPES' and 'FAPEMIG' for the financial support to this project.

\section{References}

AGOstini, T.; CECCHI, H.; BARRERA-ARELLANO, D. Caracterização química da polpa e do óleo do marolo (Annona coriaceae). Archivos Latinoamericano de Nutricion, v. 45, n. 3, p. 237-241, 1995.

ANDRADE, J. S.; ARAGÃO, C. G.; FERREIRA, S. A. Caracterização física e química dos frutos de araçá-pera (Psidium acutangulum D.C). Revista Acta Amazônica, v. 23, p. 213-217, 1993.

ASSOCIATION OF OFFICIAL ANALYTICAL CHEMISTS - AOAC. Official Methods of Analysis of Association of Official Analytical Chemists. Arlington: AOAC, 1997.

BAZIMARAKENGA, B.; SIMARD, R. R.;LEUROX, G. D. Determination of organic acids in oil extracts by ion chromatography. Soil Boilogy na Biochemistry, v. 27, p. 349-356, 1995. http://dx.doi. org/10.1016/0038-0717(94)00178-4
BEZERRA, J. E. F. et al. Frutas nativas da região Centro-Oeste do Brasil. Brasília: Embrapa Recursos Genéticos e Biotecnologia, 2006.

BITTER, V.; MUIR, H. M. A modified uronic acid carbazole reaction. Analisys Biochemistry, v. 4, p. 330-334, 1962. http://dx.doi. org/10.1016/0003-2697(62)90095-7

BORGUINI, R. G. Avaliação do potencial antioxidante e de algumas características físico-químicas do tomate (Lycopersicon esculentum) orgânico em comparação ao convencional. 2006. Tese (Doutorado em Saúde Pública)-Universidade de São Paulo, São Paulo, 2006.

BRAND-WILLIAMS, W.; CUVELIER, M. E.; BERSET, C. Use of a free radical method to evaluate antioxidant activity. Food Science and Technology, v. 28, p. 25-30, 1995.

BRASIL. Ministério da Saúde. Agência Nacional de Vigilância Sanitária. Portaria $n^{\circ} 27$, de 13 de janeiro de 1998. Regulamento Técnico referente à Informação Nutricional Complementar (declarações relacionadas ao conteúdo de nutrientes) ), constantes do anexo desta Portaria. Diário Oficial da República Federativa do Brasil, Poder Executivo, Brasília, DF, de 16 jan 1998.

CALDEIRA, S. D. et al. Caracterização físico-quimica do araça (psidium guineense Sw.) e do tarumã (Vitex cymosa Bert.) do Estado do Mato Grosso do Sul. Boletim CEPPA, v. 22, n. 1, p. 145-154, 2004.

CARVALHO, J. A. Marolo: o doce sabor do savanna; sugestões de cultivo. Machado: Folha Machadense, 2002.

COZZOLINO, S. M. F. Biodisponibilidade de nutrientes. 2 .ed. São Paulo: Manole, 2007.

DUBOIS, M. K. A. et al. Colorimetric method for determination of sugars and related substances. Analytical Chemistry, v. 28, n. 3, p. 350-355, 1956. http://dx.doi.org/10.1021/ac60111a017

FRANCO, G. Tabela de composição química dos alimentos. 9. ed. São Paulo: Atheneu, 1999.

GENOVESE, M. I. et al. Determinação do conteúdo de fenólicos totais em frutas. Revista de Ciências Farmacêuticas, v. 39, p. 167-169, 2003.

INSTITUTE OF MEDICINE. Dietary reference intakes for calcium, phosphorus, magnesium, vitamin $\mathrm{D}$ and fluoride. Washigton: National Academic, 1997.

INSTITUTE OF MEDICINE. Dietary reference intakes for vitamim $\mathrm{A}, \mathrm{K}$, arsenic, boron, chromium, copper, iodine, iron, manganese, molibdenium, nickel, silicon, vanadium and zinc. Washigton: National Academic, 2001.

LEONEL, M.; CEREDA, M. P.; ROAU, X. Aproveitamento do resíduo da produção de etanol a partir de farelo de mandioca, como fonte de fibras dietética. Revista Ciência e Tecnologia de Alimentos, v. 19, n. 2, 1999.

LORENZI, H. Árvores brasileiras: manual de identificação e cultivo de plantas arbóreas nativas do Brasil. 2. ed. São Paulo: Plantarum, 1998.

MAHATANATAWEE, K. et al. Total antioxidant activity of Floridas tropical fruit using the dpph and arac assay. American Chemical Soviety National Meeting, v. 139, p. 78-90. 2005.

MANICA, I. Frutas nativas, silvestres e exóticas 1 - Técnicas de produção e mercado: abiu, amora-preta, araça, bacuri, biriba, carambola, cereja-do-rio-grande, jabuticaba. Porto Alegre: Cinco Continentes, 2000.

MELO, J. T. Araticum. In: VIEIRA, R. F. et al. Frutas nativas da região Centro-Oeste do Brasil. Brasília: Embrapa Recursos Genéticos e Biotecnologia, 2006. 
NELSON, N. A. A photometric adaptation of Somogyi method for the determination of glucose. Journal Biology Chemistry, p. 135-375, 1944.

PEREIRA, L. M. et al. Vida de prateleira de goiabas minimamente processadas acondicionadas em embalagens sob atmosfera modificada. Ciência e Tecnologia Alimentos, v. 23, n. 3, p. 427-433, 2003.

ROESLER, R. et al. Atividade antioxidante de frutos do savanna. Ciência Tecnologia de Alimentos, v. 27, n. 1, p. 109-118, 2007.

SANTOS, C. A. F. et al. Preliminary characterization of Psidium germplasm in different Brazilian ecogeographic regions. Pesquisa Agropecuaria Brasileira, v. 43, n. 3, p. 437-440, 2008. http://dx.doi. org/10.1590/S0100-204X2008000300020

SANTOS, C. N. P. Elaboração de um estruturado de polpa de manga (Mangifera indica L. cv Tommy Atkins) parcialmente desidratada por osmose. 2003. 79 f. Dissertação (Mestrado em Tecnologia de
Alimentos)-Faculdade de Engenharia de Alimentos, Universidade Estadual de Campinas, Campinas, 2003.

SILVA, F. A. et al. Exsudação de ácidos orgânicos em rizosfera de plantas daninhas. Planta Daninha, v. 19, p. 193-196, 2001. http://dx.doi. org/10.1590/S0100-83582001000200006

SILVA, M. R. et al. Caracterização química de frutos nativos do savanna. Ciência Rural, v. 38, n. 6, p. 1790-1793, 2008.

UNIVERSIDADE DE CAMPINAS - UNICAMP. Tabela brasileira de composição de alimentos - TACO. Versão 2. 2. ed. Campinas: UNICAMP/NEPA, 2006.

WILSON, E. D.; SANTOS, A. C.; VIEIRA, E. C. Energia In: DUTRA OLIVEIRA, J. E.; SANTOS, A. C.; WILSON, E. D. Nutrição básica. São Paulo: Savier, 1982.

ZIELISKI, H., KOZOWSKA, H. Antioxidant activity and total phenolics in selected cereal grains and their different morphological fractions. Journal of Agricultural and Food Chemistry, v. 48, p. 2008-2016, 2000. http://dx.doi.org/10.1021/jf990619o 